\title{
Correction to: Type 2 Diabetes with Artificial Intelligence Machine Learning: Methods and Evaluation
}

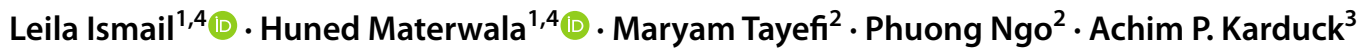

Published online: 7 October 2021

(c) The Author(s) 2021

\section{Correction to: Archives of Computational Methods in Engineering https://doi.org/10.1007/s11831-021-09582-x}

The article Type 2 Diabetes with Artificial Intelligence Machine Learning: Methods and Evaluation, written by Leila Ismail1, Huned Materwala, Maryam Tayef, Phuong Ngo, Achim P. Karduck, was originally published electronically on the publisher's internet portal on 15 April, 2021 without open access.

With the author(s)' decision to opt for Open Choice the copyright of the article changed on 15 Sept, 2021 to $\odot$ The Author(s).

Open Access This article is licensed under a Creative Commons Attribution 4.0 International License, which permits use, sharing, adaptation, distribution and reproduction in any medium or format, as long as you give appropriate credit to the original author(s) and the source, provide a link to the Creative Commons licence, and indicate if changes were made.

The images or other third party material in this article are included in the article's Creative Commons licence, unless indicated otherwise in a credit line to the material. If material is not included in the article's Creative Commons

The original article can be found online at https://doi.org/10.1007/ s11831-021-09582-x.

Leila Ismail

leila@uaeu.ac.ae

1 Intelligent Distributed Computing and Systems Research Laboratory, Department of Computer Science and Software Engineering, College of Information Technology, United Arab Emirates University, 15551 Al Ain, Abu Dhabi, United Arab Emirates

2 Norwegian Centre for E-Health Research, Troms $\emptyset$, Norway

3 Faculty of Informatics, Furtwangen University, Furtwangen, Germany

4 National Water and Energy Center, United Arab Emirates University, Al Ain, Abu Dhabi, United Arab Emirates licence and your intended use is not permitted by statutory regulation or exceeds the permitted use, you will need to obtain permission directly from the copyright holder.

To view a copy of this licence, visit http://creativeco mmons.org/licenses/by/4.0/.

Open Access This article is licensed under a Creative Commons Attribution 4.0 International License, which permits use, sharing, adaptation, distribution and reproduction in any medium or format, as long as you give appropriate credit to the original author(s) and the source, provide a link to the Creative Commons licence, and indicate if changes were made. The images or other third party material in this article are included in the article's Creative Commons licence, unless indicated otherwise in a credit line to the material. If material is not included in the article's Creative Commons licence and your intended use is not permitted by statutory regulation or exceeds the permitted use, you will need to obtain permission directly from the copyright holder. To view a copy of this licence, visit http://creativecommons.org/licenses/by/4.0/.

Publisher's Note Springer Nature remains neutral with regard to jurisdictional claims in published maps and institutional affiliations. 